\title{
AAV6- $\beta$ ARKct gene delivery mediated by molecular cardiac surgery with recirculating delivery (MCARD) in sheep results in robust gene expression and increased adrenergic reserve
}

\author{
Michael G. Katz, MD, PhD, ${ }^{\text {a,b }}$ Anthony S. Fargnoli, MS, a,b JaBaris D. Swain, MD, ${ }^{a}$ \\ Catherine E. Tomasulo, MD, ${ }^{\mathrm{a}}$ Michele Ciccarelli, $\mathrm{MD},{ }^{\mathrm{c}} \mathrm{Z}$. Maggie Huang, $\mathrm{PhD},{ }^{\mathrm{c}}$ \\ Joseph E. Rabinowitz, $\mathrm{PhD},{ }^{\mathrm{c}}$ and Charles R. Bridges, MD, $\mathrm{ScD}^{\mathrm{a}, \mathrm{b}}$
}

\begin{abstract}
Objective: Genetic modulation of heart function is a novel therapeutic strategy. We investigated the effect of molecular cardiac surgery with recirculating delivery (MCARD)-mediated carboxyl-terminus of the $\beta$-adrenergic receptor kinase ( $\beta \mathrm{ARKct}$ ) gene transfer on cardiac mechanoenergetics and $\beta$-adrenoreceptor ( $\beta \mathrm{AR})$ signaling.

Methods: After baseline measurements, sheep underwent MCARD-mediated delivery of $10^{14}$ genome copies of self-complimentary adeno-associated virus (scAAV6)- $\beta$ ARKct. Four and 8 weeks after MCARD, mechanoenergetic studies using magnetic resonance imaging were performed. Tissues were analyzed with real-time quantitative polymerase chain reaction (RT-qPCR) and Western blotting. $\beta$ AR density, cyclic adenosine monophosphate levels, and physiologic parameters were evaluated.
\end{abstract}

\begin{abstract}
Results: There was a significant increase in $\mathrm{dP} / \mathrm{dt}_{\max }$ at 4 weeks: $1384 \pm 76$ versus $1772 \pm 182 \mathrm{~mm} \mathrm{Hg} / \mathrm{s}$; and the increase persisted at 8 weeks in response to isoproterenol $(P<.05)$. Similarly, the magnitude of $\mathrm{dP} / \mathrm{dt}_{\text {min }}$ increased at both 4 weeks and 8 weeks with isoproterenol stimulation $(P<.05)$. At 8 weeks, potential energy was conserved, whereas in controls there was a decrease in potential energy $(P<.05)$ in response to isoproterenol. RT-qPCR confirmed robustness of $\beta$ ARKct expression throughout the left ventricle and undetectable expression in extracardiac tissues. Quantitative Western blot data confirmed higher expression of $\beta$ ARKct in the left ventricle: $0.46 \pm 0.05$ versus 0.00 in lung and liver $(P<.05)$. Survival was $100 \%$ and laboratory parameters of major organ function were within normal limits.
\end{abstract}

Conclusions: MCARD-mediated $\beta$ ARKct delivery is safe, results in robust cardiac-specific gene expression, enhances cardiac contractility and lusitropy, increases adrenergic reserve, and improves energy utilization efficiency in a preclinical large animal model. (J Thorac Cardiovasc Surg 2012;143:720-6)

B Supplemental material is available online.

The $\beta$-adrenergic receptor ( $\beta \mathrm{AR}$ ) system is one of the most important signaling pathways for the regulation of cardiac contractility and is therefore an attractive molecular target strategy to improve heart function. ${ }^{1,2}$ Two important

\footnotetext{
From the Division of Cardiovascular Surgery, ${ }^{\mathrm{a}}$ Department of Surgery, the University of Pennsylvania School of Medicine, Philadelphia, Pa; Sanger Heart and Vascular Institute, ${ }^{\mathrm{b}}$ Cannon Research Center Carolinas Medical Center, Charlotte, NC; and the Center for Translational Medicine and the George Zallie and Family Laboratory for Cardiovascular Gene Therapy, ${ }^{c}$ Thomas Jefferson University, Philadelphia, $\mathrm{Pa}$.

This research was supported by National Institutes of Health grant 1-R01-HL08307801A2 (to C.R.B.).

Disclosures: Authors have nothing to disclose with regard to commercial support.

M.G.K. and A.S.F. contributed equally to this article.

Received for publication April 15, 2011; revisions received July 12, 2011; accepted for publication Aug 3, 2011; available ahead of print Dec 6, 2011.

Address for reprints: Charles R. Bridges, MD, ScD, Sanger Heart and Vascular Institute, Carolinas Health Care System, 1001 Blythe Blvd, Charlotte, NC 28203 (E-mail: Charles.bridges@carolinashealthcare.org).

$0022-5223 / \$ 36.00$

Copyright (C) 2012 by The American Association for Thoracic Surgery doi:10.1016/j.jtcvs.2011.08.048
}

components of the $\beta$ AR system include the $\beta$ receptors and the regulatory $\mathrm{G}$ protein-coupled receptor kinases (GRKs), which phosphorylate and inactivate these receptors. The predominant kinase in the myocardium is GRK2. In the majority of heart failure models across species, the expression and activity of GRK2 is elevated, contributing to the lack of $\beta$-adrenergic reserve. GRK2 translocates from the cytosol to the membrane on agonist binding. GRK2 is alternatively known as $\beta$-adrenergic receptor kinase $(\beta \mathrm{ARK})$. A GRK2 inhibitor was developed to effectively reverse $\beta$ AR desensitization. It consists of the carboxyl terminus of $\beta$ ARK (GRK2), known as $\beta$ ARKct, which directly competes with GRK2 for binding to the $\beta \gamma$ subunits of heterotrimeric $G$ proteins to prevent the phosphorylation of $\beta$ ARs. ${ }^{3}$ Various experimental small animal models have confirmed a salutary effect of $\beta$ ARKct overexpression on myocardial function. ${ }^{4,5}$ However, before clinical trials can be proposed, long-term and stable myocardial expression is needed, ideally with data derived from a clinically relevant large animal model. Currently, it is unknown whether expression of the $\beta$ ARKct peptide in large animals would lead to improved contractility either at baseline or in response to adrenergic 


$$
\begin{aligned}
& \text { Abbreviations and Acronyms } \\
& \beta \mathrm{AR}= \beta \text {-adrenergic receptor } \\
& \beta \mathrm{ARK}=\beta \text {-adrenergic receptor kinase } \\
& \beta \mathrm{ARKct}= \text { carboxyl terminus of } \beta \text {-adrenergic } \\
& \text { receptor kinase } \\
& \mathrm{cAMP}= \text { cyclic adenosine monophosphate } \\
& \mathrm{CPB}=\text { cardiopulmonary bypass } \\
& \mathrm{ESPVR}= \text { end-systolic pressure-volume } \\
& \text { relationship } \\
& \mathrm{GFP}= \text { green fluorescent protein } \\
& \mathrm{dP} / \mathrm{dt}= \text { first derivative of the left ventricular } \\
& \text { intracavitary pressure } \\
& \mathrm{GRK}= \text { G protein-coupled receptor kinase } \\
& \text { iso }= \text { isoproterenol } \\
& \mathrm{LV}=\text { left ventricular } \\
& \mathrm{MCARD}= \text { molecular cardiac surgery with } \\
& \text { recirculating delivery } \\
& \mathrm{MRI}= \text { magnetic resonance imaging } \\
& \mathrm{Pmax}= \text { maximum left ventricular pressure } \\
& \mathrm{RT}-=\text { real-time quantitative polymerase } \\
& \mathrm{qPCR} \text { chain reaction } \\
& \text { scAAV }= \text { self-complimentary adeno-associated } \\
& \text { virus }
\end{aligned}
$$

stimulation. Moreover, in normal hearts, the influence of $\beta$ ARKct gene transfer on cardiac mechanoenergetics and neurohumoral systems remains incompletely resolved. ${ }^{5}$ Here we use molecular cardiac surgery with recirculating delivery (MCARD), a novel clinically translatable cardiac-specific cardiopulmonary bypass (CPB)-based gene delivery platform, for the first time ever using a therapeutic transgene. ${ }^{6}$ Our hypothesis was that MCARDmediated delivery of self-complimentary adeno-associated virus (scAAV6)-encoding $\beta$ ARKct would result in robust expression in the myocardium of an appropriate preclinical large animal model and that enhanced $\beta$ AR signaling by inhibition of GRK2 would result in an increase in adrenergic reserve.

\section{MATERIALS AND METHODS} Animals and Study Design

All animals received humane care in compliance with the National Institutes of Health and guidelines established by the Institutional Committee of the University of Pennsylvania. Six Dorsett male sheep (approximately 1 year old), weighing $40.2 \pm 2.6 \mathrm{~kg}$, were the basis for the results presented here. In the study group, design was as follows: Sheep underwent baseline magnetic resonance imaging (MRI) and echocardiographic measurements, and then $\mathrm{CPB}$ was conducted, including molecular cardiac surgery with recirculating delivery of scAAV6. $\beta$ ARKct (MCARD- $\beta$ ARKct). After 4 weeks the hemodynamic and energetic studies were carried out with MRI, and after 8 weeks these studies were repeated. The animals were then humanely killed, and tissue was harvested from the myocardium, liver, kidney, lung, testes, diaphragm, spleen, and skeletal muscle. In addition, in a separate group, 4 sheep underwent MCARD with delivery of $10^{14}$ genome copies of scAAV6 encoding green fluorescent protein (GFP). In this group, after the animals had been humanely killed after 4 weeks, myocardial specimens were analyzed for $\beta \mathrm{AR}$ density and cyclic adenosine monophosphate (cAMP) activity.

\section{Surgical Procedure and Gene Delivery}

All surgical details of the MCARD procedure have been described previously. ${ }^{6}$ We briefly discuss the main points. After heparin was administered to maintain an active coagulation time greater than 400 seconds, a transepicardial echocardiogram was used to evaluate global cardiac function before cannulation of the heart. The right carotid artery was cannulated for systemic perfusion. The aortic root vent, superior vena cava cannula, and retrograde cardioplegia catheter were then placed, initiating partial $\mathrm{CPB}$. The inferior vena cava was cannulated, full $\mathrm{CPB}$ was initiated, the right and the left azygos (hemiazygos) veins were ligated, and vent cannulas were placed into the left and right ventricular cavities. The vents were connected to the venous limb of the cardiac venous return circuit. The arterial limb of the cardiac circuit was connected to the coronary sinus catheter. The aorta was crossclamped. Cold $\left(4^{\circ} \mathrm{C}\right)$ crystalloid cardioplegic solution was delivered antegradely. The heart was isolated by tightening the snares on the superior and inferior venae cavae and crossclamping the pulmonary artery. The virus solution consisting of $10^{14}$ genome copies of scAAV6. $\beta$ ARKct, along with $60 \mu \mathrm{g}$ of vascular endothelial growth factor $\left(\mathrm{VEGF}_{165}\right.$; PeproTech, Inc, Rocky Hill, NJ), was injected into the retrograde catheter and recirculated for 20 minutes. The coronary circuit was then flushed to wash out residual vector. The aortic crossclamp was removed and flow restored. Rewarming was initiated. A postprocedure transepicardial echocardiogram confirmed maintenance of global cardiac function. The animal was subsequently weaned completely from CPB and the incision closed in standard fashion. All animal subjects recovered from anesthesia, received critical cardiac postoperative care without incident, and survived until being humanely killed at 8 weeks.

\section{MRI Analysis of Cardiac Hemodynamics and Energetics}

Cine cardiac MRI series were generated for each animal at each of 3 time points: before MCARD and 4 and 8 weeks after MCARD. Main measures were recorded before and after administration of isoproterenol (iso). Left ventricular (LV) pressure-gated images were recorded with a Millar catheter (Millar Instruments, Inc, Houston, Tex) throughout the MRI. LV volumes over the cardiac cycle were obtained with a custom image analysis package developed at the University of Pennsylvania (ImageJ) and validated with freely available Segment Cardiac MRI software (//segment.heiberg.se/). LV pressure cycles were averaged into a single representative and fit with an algorithm to the volume points based on elapsed time between phases and sampling rates to generate a pressure-volume loop. ${ }^{7}$ Pressure data from the Millar catheter were loaded into MATLAB 9.0 (MathWorks, Natick, Mass), and built-in functions were used to calculate and plot first derivative of $\mathrm{LV}$ intracavitary pressure $\left(\mathrm{dP} / \mathrm{dt}_{\max }\right.$ and $\left.\mathrm{dP} / \mathrm{dt}_{\min }\right)$ points for 5 to 10 consecutive pressure cycles. The following measures were obtained directly with several assumptions previously published with the method: stroke volume; ejection fraction; cardiac output; the maximal LV pressure of isovolumic beats extrapolated from the LV curve; the maximal value of time-varying elastance; effective arterial elastance; oxygen consumption per beat; pressure-volume area, which is analogous to total mechanical energy; and potential energy, which is the pressure-volume area outside of the loop and analogous to energy stored after ejection. A more detailed discussion of the methodology is provided in the supplementary material.

\section{Echocardiographic Analysis of Cardiac Function}

A transepicardial echocardiogram was obtained on all animals to evaluate baseline cardiac structure and function. This evaluation was repeated 
after weaning from CPB. All examinations were performed by a certified echocardiography technician. Transepicardial imaging was performed with a 7-MHz transducer (Acuson, Mountain View, Calif) using 2-dimensional, spectral Doppler and color flow Doppler modalities.

\section{Measurement of Physiologic Parameters}

Blood samples were taken for complete blood count, arterial blood gases, and to assess liver, lung, kidney, and pancreatic function. A portable chest $\mathrm{x}$-ray film was also obtained when indicated. Blood analytical studies were performed by the Antech Diagnosis Lab (Lake Success, NY).

\section{Western Blot Analysis}

Frozen cardiac tissue samples were disrupted by an Omni TH tissue homogenizer (Omni International, Kennesaw, Ga) in RIPA lysis buffer (Cell Signaling Technology, Danvers, Mass) supplemented with Complete Protease Inhibitor Cocktail (Hoffmann-La Roche, Basel, Switzerland). Tissue debris was removed by centrifugation at 13,000 rpm for 20 minutes. Resulting protein extract concentrations were quantified by using Bio-Rad Protein Assay (Bio-Rad Laboratories, Inc, Hercules, Calif) according to manufacturer's protocol. A total of $65 \mu \mathrm{g}$ of each protein sample was loaded into the cells and resolved in a NuPAGE 12\%-BT gel (Invitrogen, Carlsbad, Calif). For Western blot analysis, proteins were electrotransfered into $0.45-\mu \mathrm{m}$ Nitrocellulose membranes (Noble NC Europe Limited, Irvine, Scotland) using the Tris/CAPS buffer system at $0.8 \mathrm{~mA} / \mathrm{cm}^{2}$ for 1 hour by a TE70X semi-dry blotter. Immunostaining was done using a rabbit polyclonal anti-GRK2 antibody (Santa Cruz Bio, Calif) as a primary with peroxidase conjugated affinipure $\mathrm{F}\left(\mathrm{ab}^{\prime}\right) 2$ Fragment Goat Anti-rabbit immunoglobulin $\mathrm{G}$ antibody as a secondary and mouse monoclonal anti-glyceraldehyde3-phosphate dehydrogenase-peroxidase conjugate antibody (Sigma, Ronkonkoma, NJ). Immunodetection was done using Lumi-Light Western Blotting Substrate (Hoffmann-La Roche) and developing using Blue Light Autorad Film (Fisher Scientific, Inc, Waltham, Mass).

\section{Real-Time Quantitative Polymerase Chain Reaction}

Real-time quantitative polymerase chain reaction (RT-qPCR) was performed using the MyiQ RT PCR Detection System and analyzed using the MyiQ software package (Bio-Rad Laboratories). Tissue was excised $(50-60 \mathrm{mg})$ from 9 distinct cardiac regions and from 2 separate liver and lung lobes. The samples were disrupted in liquid nitrogen using mortar and pestle, followed by homogenization via pipetting. Total RNA was isolated using the RNeasy Fibrous Mini Kit (Quiagen, Valencia, Calif). qPCR analysis was performed in optical 96-well plates using the iQ SYBRGreen Supermix (Bio-Rad). Two sets of specific primers were used to examine the expression of $\beta$ ARKct: GRK2-forward-5'-CCCTCTCACCATCTCT GAG-3', GRK2-reverse - $5^{\prime}$-CGGTTGGGGAACAAGTAGAA- $3^{\prime}$ and $\beta$ AR Kct-forward ( $5^{\prime}$ - ATGCATGGCTACATGTCCAA- $\left.3^{\prime}\right), \beta$ ARKct-reverse $5^{\prime}$-ATCTCCTCCATGGTCAGCAG- $3^{\prime}$. Reactions were performed using the 2-step amplification method $\left(95^{\circ} \mathrm{C}\right.$ for 3 minutes, 40 cycles of $95^{\circ} \mathrm{C}$ for 10 seconds, and $60^{\circ} \mathrm{C}$ for 1 minute). The level of $18 \mathrm{~S}$ rRNA was used to calculate normalized expression.

\section{Vector Design and Production}

A recombinant scAAV6 vector, encoding the $\beta$ ARKct under the control of the human immediate early cytomegalovirus gene promoter with a splice donor/acceptor sequence and polyadenylation signal from the humanglobin gene was constructed (scAAV6. cytomegalovirus gene promoter$\beta$ ARKct) as previously described. ${ }^{5}$ A schematic of GRK $2 / \beta$ ARKct protein constructs is shown in Figure E1.

\section{$\beta$ AR Density and Adenyl Cyclase Activity}

Adenyl cyclase activity was estimated indirectly by measuring cAMP. ${ }^{7}$ $\beta$ AR binding assays were performed from myocardial sarcolemmal membranes, as described previously. ${ }^{8}$

\section{Histologic Examination}

Cardiac sections were frozen in embedding compound and sectioned into 5- $\mu \mathrm{m}$ slices. Hematoxylin and eosin and Masson trichrome staining were performed on microscopic sections and examined for evidence of myocardial injury.

\section{Statistical Analysis}

Data are presented as mean \pm standard error of the mean. Single-factor analysis of variance was used to compare the baseline values for all cardiac mechanics parameters for the following 3 time points: control or pre-gene transfer, 4 weeks after $\beta$ ARKct transfer, and 8 weeks after BARKct transfer. Multiple group comparisons for RT-qPCR and Western blot expression were also analyzed by single-factor analysis of variance. For comparisons of iso $=0$ versus iso $=0.5 \mu \mathrm{g} / \mathrm{min}$ within a given group in a given time period, a paired $t$ test was used.

\section{RESULTS \\ Operative Results}

All of the animals survived and resumed normal activities before being humanely killed. Average CPB and crossclamp times were $119 \pm 14.1$ and $59.9 \pm 7.8$ minutes, respectively. All animals were weaned from CPB without continuous inotropic support and extubated within 3 to 5 hours of surgery. Sheep received postoperative management reminiscent of that used to manage post-CPB patients. One of the sheep had right lower lobe pneumonia that clinically improved with antibiotic therapy. We did not observe other complications. Analysis of stained histologic sections of all parts of the atria and ventricles revealed no signs of inflammation, myocardial edema, necrosis, or fibrosis in any samples procured after they were humanely killed at 8 weeks.

\section{Effects of MCARD- $\beta$ ARKet on LV Mechanics}

The hemodynamic consequences of MCARD delivery of AAV6. $\beta$ ARKct were examined by use of dynamic intracavitary MRI pressure-volume measurements. LV intracavitary pressure $\left(\mathrm{dP} / \mathrm{dt}_{\text {max }}\right)$ was used as a measure of global $\mathrm{LV}$ contractile performance and $\mathrm{dP} / \mathrm{dt}_{\min }$ was used as a measure of global ventricular relaxation. Hemodynamics was assessed for each sheep in the study at baseline and at 4 and 8 weeks after gene delivery. Thus, each animal served as its own control, increasing the power of the analysis. There is a significant increase in $\mathrm{dP} / \mathrm{dt}_{\max }$ after iso injection at the 4-week point, increasing from $1384 \pm 76 \mathrm{~mm} \mathrm{Hg} / \mathrm{s}$ (iso $=0)$ to $1772 \pm 182 \mathrm{~mm} \mathrm{Hg} / \mathrm{s}$ (iso $=0.5 \mu \mathrm{g} / \mathrm{min}$ ) $(P<.05)$. This increase in $\mathrm{dP} / \mathrm{dt}_{\max }$ in response to iso was also significant at 8 weeks $(P<.05)$ (Figure $1, A)$. Similarly lusitropy improved at both 4 weeks and 8 weeks in response to iso. $\mathrm{dP} / \mathrm{dt}_{\min }$ decreased significantly after iso stimulation compared with baseline at both the 4-week and 8-week time points $(P<.05)$ (Figure $1, B)$. Thus, long-term $\beta$ ARKct expression results in stable improvements in contractility and in cardiac relaxation. There was also a significant increase in the cardiac output from $2937 \pm 307 \mathrm{~mL} / \mathrm{min}$ to $3629 \pm$ $435 \mathrm{~mL} / \mathrm{min}$ at 8 weeks in response to iso $(P<.05)$ (Table E1), but no change in end-systolic elastance (Table E2). 


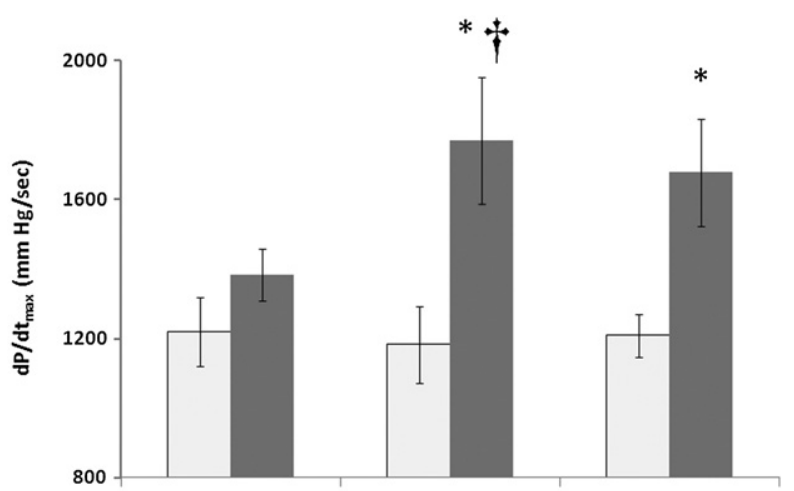

A

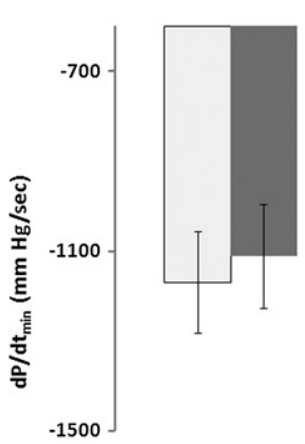

B

FIGURE 1. Effects of MCARD- $\beta$ ARKct gene transfer on LV mechanics. $\mathrm{A}, \mathrm{dP} / \mathrm{dt}_{\max } . \mathrm{B}, \mathrm{dP} / \mathrm{dt}_{\min } * P<.05$; iso $=0.5 \mu \mathrm{g} / \min$ (dark bars) versus iso $=0$ (light bars); $\uparrow P<.05,4$ weeks versus control.

\section{Effects of MCARD- $\beta$ ARKct on $\mathbf{L V}$ Energetics}

Figure 2, A, demonstrates that in the control animals, there is a significant reduction in potential energy in response to iso infusion $(P<.05)$. The reduction diminishes at 4 weeks, and at 8 weeks the change in potential energy is no longer significant. Thus, $\beta$ ARKct gene expression preserves potential energy after adrenergic stimulation, indicating improved energy efficiency. There is also a significant increase in arterial elastance in response to iso at 4 weeks $(P<.05)$ and a similar trend at 8 weeks (Figure 2, $B)$. The impact of $\beta$ ARKct gene expression on all mechanoenergetics data is illustrated in Table E2.

\section{Effects of MCARD- $\beta$ ARKet on Cardiac and Collateral Gene Expression: RT-qPCR and Western Blot Data}

In Figure 3 we illustrate the RT-qPCR results comparing the normalized ratios of $\beta$ ARKct/GRK2 messenger RNA from 4 regions of the heart with the liver and lung for 6 sheep. The liver and lung (as well as other organs, data not shown) have essentially zero detectable $\beta$ ARKct gene expression since in the absence of exogenous $\beta$ ARKct the ratio should equal 1 . In contrast, the LV lateral wall, anterior wall, and septal walls showed very high ratios of $\beta$ ARKct/ GRK2 messenger RNA with a ratio of nearly 70 in the

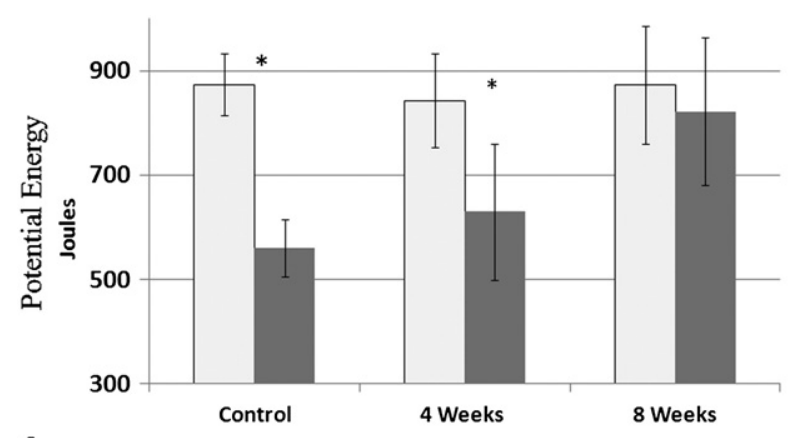

A

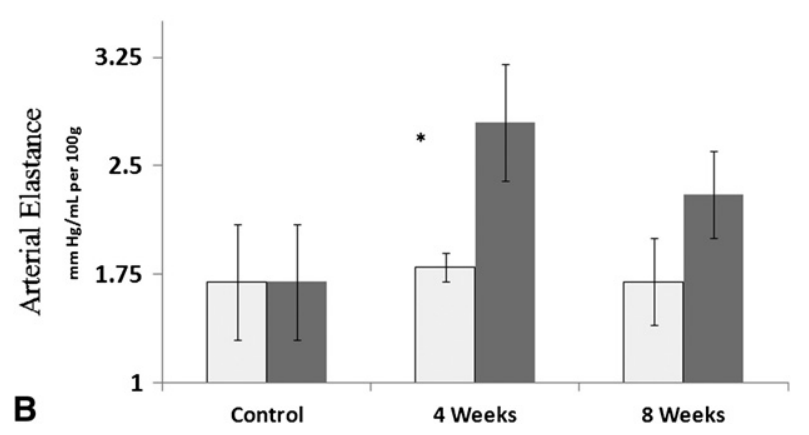

FIGURE 2. A, Effect of MCARD- $\beta$ ARKct gene transfer on potential energy. $* P<.05$; iso $=0.5 \mu \mathrm{g} / \mathrm{min}$ (dark bars) versus iso $=0$ (light bars) $\mathrm{B}$, Effect of MCARD- $\beta$ ARKct gene transfer on arterial elastance $* P<.05 ;$ iso $=0.5 \mu \mathrm{g} / \mathrm{min}($ dark bars $)$ versus iso $=0$ (light bars $)$.

anterior wall. Higher LV gene expression compared with lung or liver expression is also confirmed by analysis of variance, rejecting the null hypothesis $(P<.001)$, supporting both the high level cardiac $\beta$ ARKct expression and the exquisite cardiac-specificity of the MCARD method.

Quantitative densitometric analysis of the Western blot data illustrated in Figure 4, $A$, reveals that there was higher expression of $\beta$ ARKct in the left ventricle (all regions combined) $0.46 \pm 0.05$ versus 0.00 in lung and liver (as well as other organs, data not shown), further support the cardiac specificity of the MCARD method. The left ventricle has the most intense $\beta$ ARKct gene expression. We did not find a significant difference between anterior, lateral, posterior wall, and septum by analysis of variance $(P>.05)$ (Figure 4, $B$ and $C$ ).

\section{Effect of MCARD- $\beta$ ARKet on Cardiac cAMP Activity and $\beta$ AR Density}

At the end of the 8-week study we compared the levels of cAMP in the myocardium to determine whether this $\beta$ ARmediated second messenger was altered. We also measured total $\beta \mathrm{AR}$ density in plasma membranes isolated from all ovine hearts and compared the results with tissues derived from a separate group of animals after MCARD-GFP gene delivery. As shown in Figure 5, A, mean cAMP levels were increased in hearts overexpressing $\beta$ ARKct compared with myocardial membranes prepared from GFP-treated 


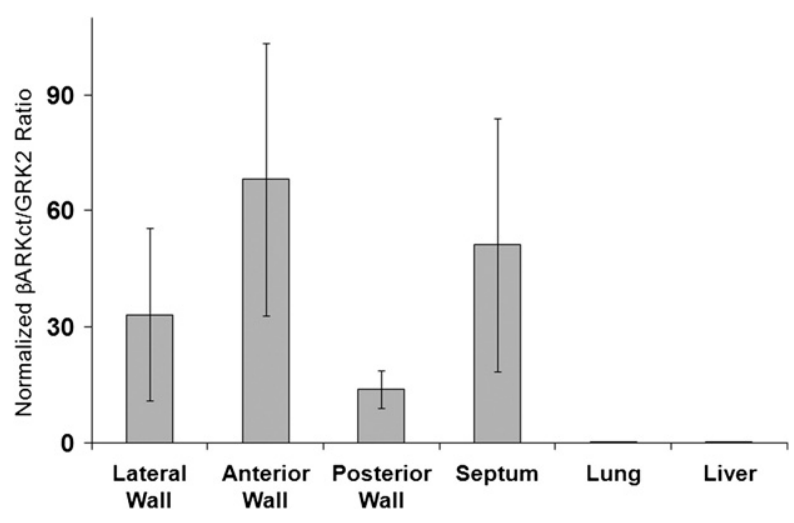

FIGURE 3. RT-qPCR: MCARD- $\beta$ ARKct left ventricle and collateral expression.

sheep. Mean LV $\beta$ AR density was also higher after MCARD- $\beta$ ARKct compared with animals that had undergone the MCARD procedure without therapeutic gene delivery (MCARD-GFP) (Figure 5, B). However, these differences in mean values were not statistically significant.

\section{Physiologic Consequences After MCARD- $\beta$ ARKct Gene Delivery}

All major organ systems (blood, cardiac, pulmonary, gastrointestinal, and kidney) were assessed preoperatively and postoperatively. The physiologic data are summarized in Table E3. The mean values of all parameters at 8 weeks after MCARD-mediated $\beta$ ARKct delivery were generally within normal limits. Transepicardial echocardiograms revealed normal right ventricular, $\mathrm{LV}$, and valvular function both before and after MCARD without any new wall motion abnormalities (Table E4).

\section{DISCUSSION}

In 1990, Lin and associates ${ }^{9}$ injected plasmid DNA into the left ventricle and demonstrated gene expression in
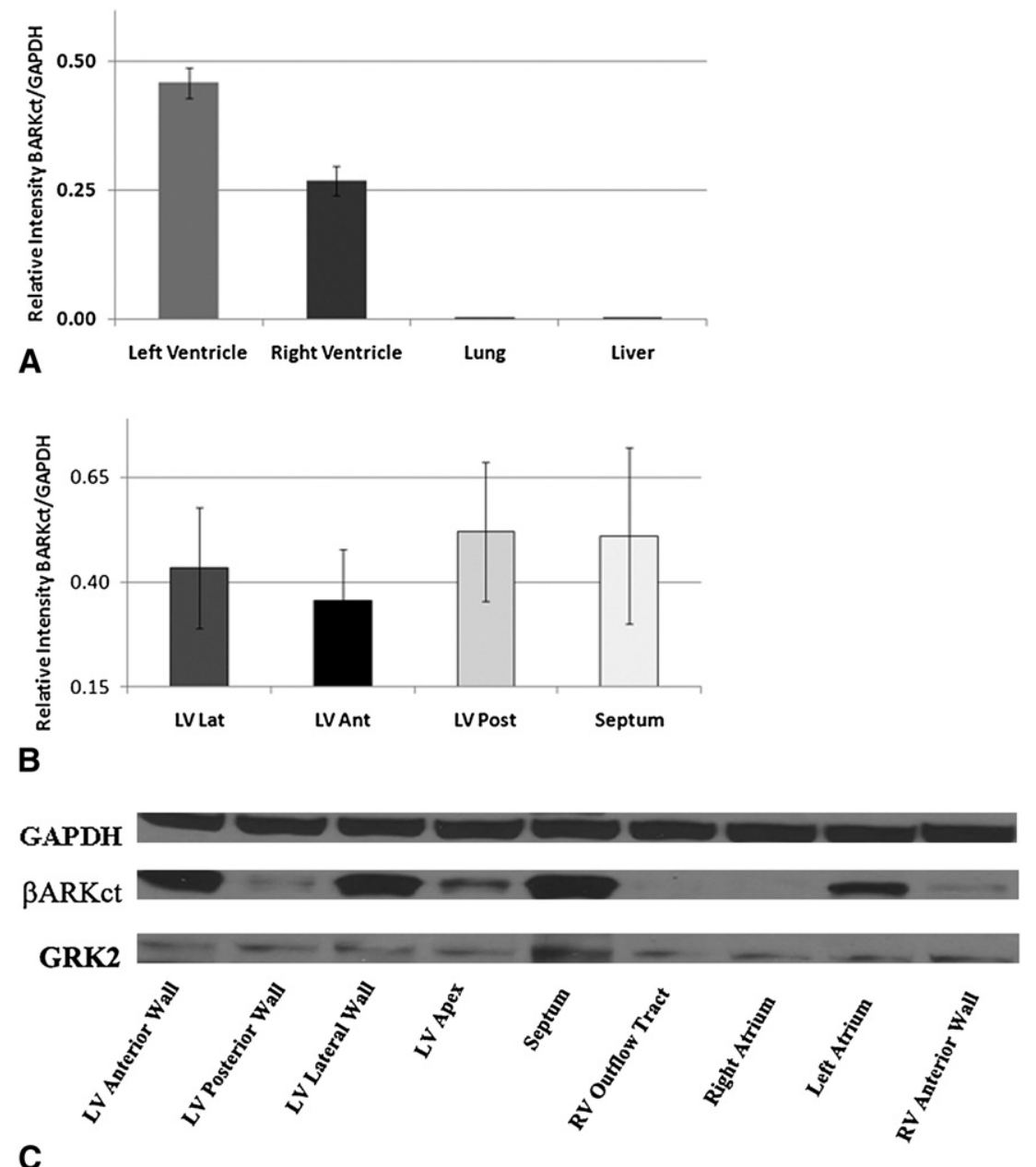

FIGURE 4. A, MCARD- $\beta$ ARKct quantitative Western blot analysis: left and right ventricles versus lung and liver. B, MCARD- $\beta$ ARKct quantitative Western blot analysis: LV regional expression. C, MCARD- $\beta$ ARKct Western blot: left ventricle, lung, and liver. GAPDH, Glyceraldehyde-3-phosphate dehydrogenase; $L V$, left ventricular; $R V$, right ventricular. 


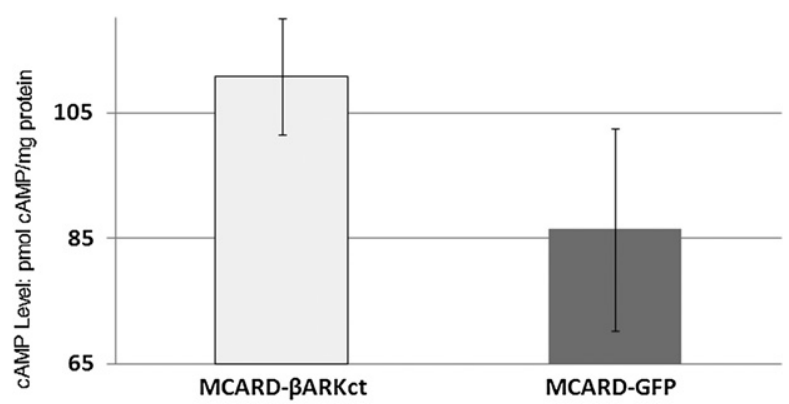

A

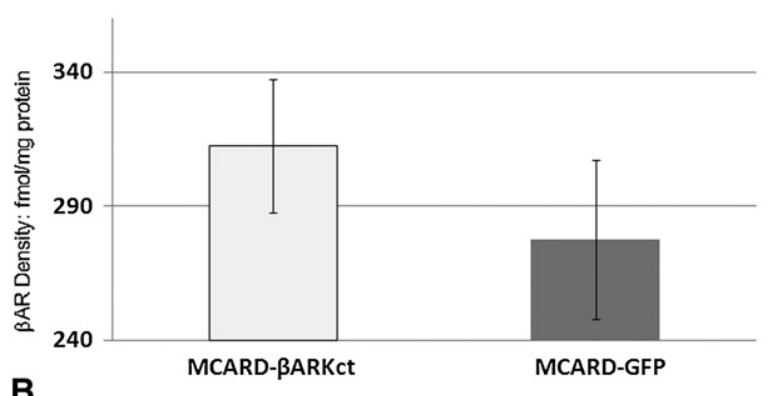

FIGURE 5. A, Cardiac cAMP level: MCARD- $\beta$ ARKct versus MCARDGFP. B, Cardiac $\beta$ AR density: MCARD- $\beta$ ARKct versus MCARD-GFP.

myocytes. This study ushered in the arrival of molecular technologies to modern cardiology and cardiac surgery. Over the past 2 decades, there have been substantial advances in vector systems, in the availability of potentially therapeutic genes, and in techniques of gene delivery. We chose recombinant AAV vector, serotype 6, because it is cardiotrophic, ${ }^{10}$ results in long-term expression, ${ }^{11}$ evokes minimal cellular immune response, ${ }^{12}$ and is highly efficient. ${ }^{13}$ Furthermore, in our hands significant titers of the self-complimentary AAV6 serotype could be obtained. Despite the apparent complexity, the MCARD method of myocardial gene delivery used here has several advantages: (1) increased vector residence time in the coronary circulation, (2) minimal collateral organ gene expression, (3) allowing for washout of vector after gene transfer, and (4) the potential for translation into cardiac surgery clinical practice.

Two areas of potential heart failure gene therapy targets have been under intense study over the past decade. They include manipulation of myocyte $\beta$-adrenergic signaling and alteration of intracellular calcium-handling proteins. ${ }^{1,12}$ A variety of studies have underscored the importance of the $\beta$-adrenergic signaling abnormalities in cardiac surgery. ${ }^{14-16}$ Our main goal in this study was to determine whether MCARD-mediated delivery of $\beta$ ARKct to normal myocytes would enhance the response to adrenergic stimulation by increasing adrenergic signaling. We provide evidence in a large animal model that $\beta$ ARKct-mediated GRK2 inhibition increases the inotropic and lusitropic response to iso and supports the related hypothesis that overexpression of $\beta$ ARs can enhance cardiac function. ${ }^{3,5}$ Thus, even in the normal state, GRK2 may modulate contractility. The $\beta$ ARKct mechanism involves competitive inhibition of the $\mathrm{G} \beta \gamma$-mediated activation of GRK2, and the beneficial effects of this peptide may include enhanced signaling through other $G$ protein coupled receptors that are targets for this GRK. Moreover, there may be inhibition of other as yet unidentified $\mathrm{G}_{\beta \gamma}$ effectors. ${ }^{17,18}$ We did not find significant differences in epinephrine or norepinephrine plasma concentrations at 4 and 8 weeks after $\beta$ ARKct gene expression (data not shown), perhaps owing to the high variability of these values in normal sheep. Clinically popular load-dependent indices of cardiac contractility are not always satisfactory, and therefore pressure-volume relations may add important information about ventricular pump performance, interaction (coupling) between the ventricles and systemic and pulmonary circuits, as well as external work and potential energy associated with contraction within a cardiac cycle. ${ }^{19,20}$ Recent developments in hardware and software have enabled us to provide the MRI-mediated pressurevolume loops under real-time imaging. Given this consideration, we tried to assess the effectiveness of MCARD- $\beta$ ARKct from the standpoint of ventricular mechanics and energetic status. In this study, we demonstrated that $\beta$ ARKct gene expression significantly preserves potential energy and increases effective arterial elastance, a measure of LV-arterial coupling efficiency. The increase in arterial elastance may have been attributable to the elevation of arterial load with stable arterial resistance secondary to the overstimulation of the $\beta \mathrm{AR}$ receptors with iso. The subsequent preservation of potential energy in response to iso at 8 weeks was suggestive of an induced improvement in energy efficiency. The present study demonstrates that both the MCARD procedure and $\beta$ ARKct gene expression appear to be safe with no untoward effects on multiple organ function. MCARD is unique among all proposed cardiac gene delivery methods (intracoronary, intramuscular, intravenous) in that it virtually eliminates systemic spillage of the vector/gene, minimizing exposure of other organs to either the gene or the vector caspid, enhancing its cardiac gene delivery efficiency, and dramatically reducing the likelihood of a T cell-mediated immune response. ${ }^{6}$ Furthermore, given that the cardiac circulation is isolated from the systemic circulation, patients with pre-existing humoral immunity against the vector caspid who are currently excluded from intracoronary delivery-based trials (up to $40 \%$ of patients in the CUPID trial $)^{21}$ may be candidates for MCARD-mediated therapeutic gene delivery.

\section{Study Limitations}

The present experiments were performed in normal sheep without evidence of coronary artery disease or heart failure. Budgetary concerns precluded comparison of our data with an MCARD-empty virus group or vascular endothelial 
growth factor-only group, and we have not evaluated mechanoenergetics when using different doses of $\beta$ ARKct.

\section{CONCLUSIONS}

During 8 weeks after gene transfer, GRK2 inhibition with the MCARD technique resulted in enhancement of cardiac contractility and relaxation, preservation of $\beta \mathrm{AR}$ signaling, and improvement of energy use efficiency in a large animal model. MCARD resulted in robust myocardial gene expression with essentially no detectable extracardiac gene expression. Transfection of the ovine myocardium with scAAV6. $\beta$ ARKct had no demonstrable toxic effects on major organ function, supporting the potential role of both the MCARD delivery platform and $\beta$ ARKct therapeutic gene for heart failure gene therapy in future clinical applications.

We thank Walter J. Koch, PhD, for helpful discussion. J. Kurt Chuprun, $\mathrm{PhD}$, deserves thanks as well for contributions in $\beta \mathrm{AR}$ density and signaling studies. We thank Hansell Stedman, MD, Michael Petrov, MD, Charles Yarnall, CCP, and Alice Isidro, PA-C, for excellent technical assistance. Further, we thank the veterinarians and veterinary technicians of the University of Pennsylvania and the Gene Therapy Resource Program of the National Institutes of Health.

\section{References}

1. Lefkowitz RJ, Rockman HA, Koch WJ. Catecholamines, cardiac $\beta$-adrenergic receptors, and heart failure. Circulation. 2000;101:1634-7.

2. Rockman HA, Koch WJ, Lefkowitz RJ. Seven-transmembrane-spanning receptors and heart function. Nature. 2002;415:206-12.

3. Koch WJ, Rockman HA, Samama P, Hamilton RA, Bond RA, Milano CA, et al. Cardiac function in mice overexpressing the $\beta$-adrenergic receptor kinase or a $\beta$ ARK inhibitor. Science. 1995;268:1350-3.

4. Emani SM, Shah AS, Bowman MK, White DC, Emani S, Glower DD, et al. Right ventricular targeted gene transfer of a beta-adrenergic receptor kinase inhibitor improves ventricular performance after pulmonary artery banding. J Thorac Cardiovasc Surg. 2004;127:787-93.

5. Rengo G, Lymperopoulos A, Zincarelli C, Donniacuo M, Soltys S, Rabinowitz JE, et al. Myocardial adeno-associated virus serotype 6-BARKct gene therapy improves cardiac function and normalizes the neurohormonal axis in chronic heart failure. Circulation. 2009;119:89-98.

6. White JD, Thesier DM, Swain JD, Katz MG, Tomasulo C, Henderson A, et al. Myocardial gene delivery using molecular cardiac surgery with recombinant adeno-associated virus vectors in vivo. Gene Ther. 2011;18:546-52.

7. Kuehne T, Yilmaz S, Steendijk P, Moore P, Groenink M, Saaed M, et al. Magnetic resonance imaging analysis of right ventricular pressure-volume loops. Circulation. 2004;110:2010-6.

8. Shah AS, Atkins BZ, Hata JA, Tai O, Kypson AP, Lilly RE, et al. Early effects of right ventricular volume overload on ventricular performance and $\beta$-adrenergic signaling. J Thorac Cardiovasc Surg. 2000;119:342-9.

9. Lin H, Parmacek M, Morle G, Bolling S, Leiden J. Expression of recombinant genes in the myocardium in vivo after direct injection of DNA. Circulation. 1990;82:2217-21.

10. Zincarelli C, Soltys S, Rengo G, Koch WJ, Rabinowitz JE. Comparative cardiac gene delivery of adeno-associated virus serotypes 1-9 reveals that AAV6 mediates the most efficient transduction in mouse heart. Clin Transl Sci. 2010; 3:81-9.

11. Chu D, Sullivan CC, Weitzman MD, Du L, Wolf PL, Jamieson SW, et al. Direct comparison of efficiency and stability of gene transfer into the mammalian heart using adeno-associated virus versus adenovirus vectors. J Thorac Cardiovasc Surg. 2003;126:671-9.

12. Chaudhri BB, del Monte F, Harding SE, Hajjar RJ. Gene transfer in cardiac myocytes. Surg Clin North Am. 2004;84:141-59.

13. Hajjar RJ, Samulski RJ. A silver bullet to treat heart failure. Gene Ther. 2006;13: 997.

14. Nayak L, Rosengart TK. Gene therapy for heart failure. Semin Thorac Cardiovasc Surg. 2005; 17:343-7.

15. Bulcao CF, Pandalai PK, D'Souza KM, Merill WH, Akhter SA. Uncoupling of myocardial beta-adrenergic receptor signaling during coronary artery bypass grafting: the role of GRK2. Ann Thorac Surg. 2008;86:1189-94.

16. Tevaearai HT, Eckhart AD, Shotwell KF, Wilson K, Koch WJ. Ventricular dysfunction after cardioplegic arrest is improved after myocardial gene transfer of a beta-adrenergic receptor kinase inhibitor. Circulation. 2001;104: 2069-74.

17. Yatani A, Brown AM. Rapid beta-adrenergic modulation of cardiac calcium channel currents by a fast G protein pathway. Science. 1989;245:71-4.

18. Brinks H, Koch WL. $\beta$ ARKct: a therapeutic approach for improved adrenergic signaling and function in heart disease. J Cardiovasc Trans Res. 2010;3: 499-506.

19. Suga H. Ventricular energetics. Physiol Rev. 1990;70:247-77.

20. Sagawa K. The ventricular pressure-volume diagram revised. Circ Res. 1978;43: 677-87.

21. Jaski BE, Jessup ML, Mancini DM, Cappola TP, Pauly DF, Greenberg B, et al. Calcium upregulation by percutaneous administration of gene therapy in cardiac disease (CUPID Trial), a first-in-human phase 1/2 clinical trial. J Card Fail. 2009; 15:171-81. 


\section{E-MATERIALS AND METHODS Pressure-Volume Loop Analysis}

The standard cardiac parameters of stroke volume (end-diastolic volumeend-systolic volume), ejection fraction (stroke volume/end-diastolic volume), and cardiac output (stroke volume $\times$ heart rate in beats per minute) were derived in a straightforward manner from the MRI scans. Establishing the end-systolic pressure-volume relationship (ESPVR) and energetics model through pressure-volume loop analysis was more complex inasmuch as we could not perform occlusions in our MRI protocol. We relied on previous published methodology to extrapolate the ESPVR via singlebeat estimation of the pressure-volume loop generated from MRI. We provide the key reference, which describes our derivation of ESPVR, as well as other energetics parameters based on the definitions of Suga and associates. ${ }^{7,19,20}$

The concept of the single-beat ESPVR was realized when it was discovered that the maximum theoretical LV pressure (Pmax) value found in traditional conductance catheter experiments with occlusion could be accurately estimated with an analytical method applied to the raw LV pressure curve. This concept was validated by Suga and associates in a series of canine experiments that compared ESPVR data derived from occlusion and nonocclusion methods, whereby Pmax values were nearly identical. The basis of this correlation is the application of first-order Fourier transform to representative pressure points during the isovolumic contraction phase of the cardiac cycle (ie, just before $\mathrm{dP} / \mathrm{dt}_{\max }$ and after $\mathrm{dP} / \mathrm{dt}_{\min }$ ). The key assumption with isovolumic contraction is that it occurs primarily at end-diastole, thus allowing the Pmax to interpolate at the end-diastolic region of the single-beat LV loop. The definition in the model for ESPVR is simply $=(\mathrm{Pmax}-\mathrm{P}$ Es $) / \mathrm{SV}$ or the resultant slope of the interpolated Pmax, EDV and P Es, ESV data points (where P Es is end-systolic pressure, $\mathrm{SV}$ is stroke volume, and ESV is end-systolic volume).

Inasmuch as our method did not incorporate occlusions to alter preload/ afterload, we could not obtain a value for the standard volume condition We therefore assigned a value of 0 for each animal and calculated the pressure-volume area as the sum of the area contained in the single pressure-volume loop + triangular area one half times pressure at endsystole $\times$ end-systolic volume.

We acknowledge this assumption compromises the traditional methodology; however, our clear goal was to identify any shift in the pressurevolume relationship, that is, loop shifting right or left indicating a major energetic change. Despite its apparent limitation, we believe our fixed standard volume assumption is warranted in this study inasmuch as these were normal hearts and presented with very similar baseline function.
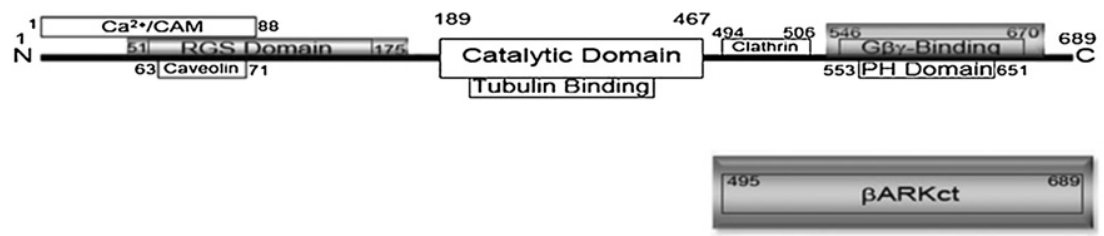

FIGURE E1. A schematic of GRK2/ $\beta$ ARKct protein constructs. $\beta A R K c t$, Carboxyl terminus of $\beta$-adrenergic receptor kinase (modified from Brinks H, Koch WL. $\beta$ ARKct: a therapeutic approach for improved adrenergic signaling and function in heart disease. J Cardiovasc Trans Res. 2010;3:499-506.) 
TABLE E1. Summary of hemodynamic data before and after MCARD- $\beta$ ARKct gene transfer

\begin{tabular}{|c|c|c|c|c|c|c|}
\hline & \multicolumn{2}{|c|}{ Before MCARD } & \multicolumn{2}{|c|}{ Four weeks after MCARD } & \multicolumn{2}{|c|}{ Eight weeks after MCARD } \\
\hline & Iso $=\mathbf{0}$ & Iso $=0.5 \mu \mathrm{g} / \mathrm{h}$ & Iso $=\mathbf{0}$ & Iso $=0.5 \mu \mathrm{g} / \mathrm{h}$ & Iso $=\mathbf{0}$ & Iso $=0.5 \mu \mathrm{g} / \mathrm{h}$ \\
\hline $\mathrm{dP} / \mathrm{dt}_{\mathrm{MAx}}(\mathrm{mm} \mathrm{Hg} / \mathrm{s})$ & $1221 \pm 99$ & $1384 \pm 76$ & $1182 \pm 110$ & $1772 \pm 182 * \dagger$ & $1209 \pm 61$ & $1679 \pm 155^{*}$ \\
\hline $\mathrm{dP} / \mathrm{dt}_{\mathrm{MIN}}(\mathrm{mm} \mathrm{Hg} / \mathrm{s})$ & $-1169 \pm 113$ & $-1112 \pm 116$ & $-1106 \pm 103$ & $-1317 \pm 137^{*}$ & $-1132 \pm 81$ & $-1295 \pm 92 *$ \\
\hline $\mathrm{CO}(\mathrm{mL} / \mathrm{min})$ & $2874 \pm 485$ & $2907 \pm 381$ & $2450 \pm 200$ & $2942 \pm 555$ & $2937 \pm 307$ & $3629 \pm 435^{*}$ \\
\hline $\mathrm{EF}(\%)$ & $58.7 \pm 5.0$ & $65.9 \pm 2.6$ & $57.8 \pm 3.7$ & $60.2 \pm 5.6$ & $55.3 \pm 5.2$ & $57.8 \pm 3.7$ \\
\hline $\mathrm{SV}(\mathrm{mL})$ & $32.0 \pm 5.9$ & $27.9 \pm 3.8$ & $30.2 \pm 2.8$ & $23.2 \pm 4.7$ & $31.8 \pm 4.4$ & $26.5 \pm 3.0$ \\
\hline
\end{tabular}

MCARD, Molecular cardiac surgery with recirculating delivery; iso, isoproterenol; $d P / d t$, first derivative of the left ventricular intracavitary pressure (maximum and minimum); $C O$, cardiac output; $E F$, ejection fraction; $S V$, stroke volume. $* P<.05$ between iso $=0$ versus iso $=0.5 \mu \mathrm{g} / \mathrm{h}$ groups at each time point (before MCARD and at 4 and 8 weeks). $\dagger P<.05$ between iso $=0.5 \mu \mathrm{g} / \mathrm{h}$ (before MCARD) versus iso $=0.5 \mu \mathrm{g} / \mathrm{h} 4$ week time points.

TABLE E2. Summary of energetics data before and after MCARD- $\beta$ ARKct gene transfer

\begin{tabular}{|c|c|c|c|c|c|c|}
\hline \multirow{2}{*}{$\begin{array}{l}\text { All variables indexed to } \\
100 \mathrm{~g} \text { of } L V \text { mass }\end{array}$} & \multicolumn{2}{|c|}{ Before MCARD } & \multicolumn{2}{|c|}{ Four weeks after MCARD } & \multicolumn{2}{|c|}{ Eight weeks after MCARD } \\
\hline & Iso $=\mathbf{0}$ & Iso $=0.5 \mu \mathrm{g} / \mathrm{h}$ & Iso $=\mathbf{0}$ & Iso $=0.5 \mu \mathrm{g} / \mathrm{h}$ & Iso $=\mathbf{0}$ & Iso $=0.5 \mu \mathrm{g} / \mathrm{h}$ \\
\hline $\mathrm{E}_{\max }(\mathrm{mm} \mathrm{Hg} / \mathrm{mL})$ & $5.0 \pm 1.2$ & $6.1 \pm 2.0$ & $4.8 \pm 1.8$ & $5.2 \pm 1.0$ & $4.2 \pm 1.7$ & $4.6 \pm 0.7$ \\
\hline Potential energy $(\mathrm{mm} \mathrm{Hg} \cdot \mathrm{mL})$ & $873 \pm 59$ & $561 \pm 55^{*}$ & $843 \pm 90$ & $630 \pm 130^{*}$ & $872 \pm 113$ & $822 \pm 141$ \\
\hline Oxygen consumption (mL/beat) & $0.09 \pm 0.01$ & $0.08 \pm 0.01$ & $0.08 \pm 0.01$ & $0.06 \pm 0.01$ & $0.08 \pm 0.01$ & $0.07 \pm 0.01$ \\
\hline End-arterial elastance $(\mathrm{mm} \mathrm{Hg} / \mathrm{mL})$ & $1.7 \pm 0.4$ & $1.7 \pm 0.4$ & $1.8 \pm 0.1$ & $2.8 \pm 0.4^{*}$ & $1.7 \pm 0.3$ & $2.3 \pm 0.3$ \\
\hline External work (joules) & $2551 \pm 447$ & $2098 \pm 227$ & $2187 \pm 267$ & $1685 \pm 308$ & $2316 \pm 409$ & $2050 \pm 183$ \\
\hline Pressure-volume area $(\mathrm{mm} \mathrm{Hg} \cdot \mathrm{mL})$ & $3425 \pm 403$ & $2658 \pm 275$ & $3030 \pm 268$ & $2315 \pm 403$ & $3188 \pm 433$ & $2872 \pm 288$ \\
\hline
\end{tabular}

MCARD, Molecular cardiac surgery with recirculating delivery; iso, isoproterenol; $L V$, left ventricular; $E_{\text {max }}$, end-systolic elastance. $* P<.05$ between iso $=0$ versus iso $=0.5 \mu \mathrm{g} /$ $\mathrm{h}$ groups at each time point (before MCARD and at 4 and 8 weeks). 
TABLE E3. Physiologic data after MCARD- $\beta$ ARKet gene transfer

\begin{tabular}{|c|c|c|c|c|}
\hline & Units & Reference range & Before & After \\
\hline \multicolumn{5}{|l|}{ Complete blood count } \\
\hline A. Hemoglobin & $g / L$ & $90-140$ & $123 \pm 4$ & $110 \pm 4$ \\
\hline B. Total WBC & $10^{9} / \mathrm{L}$ & $4.0-13.0$ & $6.2 \pm 0.3$ & $6.9 \pm 0.5$ \\
\hline C. Platelets & $10^{9} / \mathrm{L}$ & $250-750$ & $406 \pm 29$ & $416 \pm 52$ \\
\hline D. Neutrophils & & $0.7-6$ & $3.8 \pm 0.2$ & $3.9 \pm 0.2$ \\
\hline E. Lymphocytes & & $2-9$ & $4.6 \pm 0.3$ & $5.0 \pm 0.3$ \\
\hline \multicolumn{5}{|l|}{ Respiratory system } \\
\hline A. Oxygen saturation & $\%$ & 96-100 & $99.3 \pm 0.3$ & $97.7 \pm 0.4$ \\
\hline B. Arterial blood gases & & normal/pathol & normal & normal \\
\hline C. Chest $\mathrm{x}$-ray film and ultrasound & & normal/pathol & normal & normal \\
\hline \multicolumn{5}{|l|}{ Renal system } \\
\hline A. Urea nitrogen & $\mathrm{mmol} / \mathrm{L}$ & $2.9-7.1$ & $5.99 \pm 0.43$ & $5.71 \pm 0.46$ \\
\hline B. Creatinine & $\mu \mathrm{mol} / \mathrm{L}$ & $106-168$ & $124 \pm 9$ & $123 \pm 27$ \\
\hline \multicolumn{5}{|l|}{ Gastrointestinal system } \\
\hline A. Motility and contraction & & normal/pathol & normal & normal \\
\hline \multicolumn{5}{|l|}{ B. Liver function } \\
\hline 1. ALT & $\mathrm{U} / \mathrm{L}$ & $26-34$ & $30.8 \pm 2.1$ & $30.8 \pm 2.5$ \\
\hline 2. AST & $\mathrm{U} / \mathrm{L}$ & $250-350$ & $297 \pm 9.6$ & $282 \pm 15$ \\
\hline 3. Alkaline phosphatase & $\mathrm{U} / \mathrm{L}$ & $50-200$ & $69.8 \pm 4.2$ & $63.2 \pm 2.8$ \\
\hline 4. Bilirubin & $\mu \mathrm{mol} / \mathrm{L}$ & $1.7-8.6$ & $6.8 \pm 1.7$ & $8.6 \pm 1.7$ \\
\hline \multicolumn{5}{|l|}{ C. Pancreatic function } \\
\hline 1. Lipase & $\mathrm{U} / \mathrm{L}$ & $5-35$ & $14.3 \pm 1.0$ & $17.8 \pm 1.1$ \\
\hline 2. Amylase & $\mathrm{U} / \mathrm{L}$ & $4-30$ & $17.2 \pm 1.4$ & $13.5 \pm 1.4$ \\
\hline 3. Glucose & $\mathrm{mmol} / \mathrm{L}$ & $2.5-4.5$ & $2.8 \pm 0.2$ & $4.0 \pm 0.2$ \\
\hline
\end{tabular}

MCARD, Molecular cardiac surgery with recirculating delivery; $\beta A R K c t$, carboxyl terminus of $\beta$-adrenergic receptor kinase; $W B C$, white blood cells; $A L T$, alanine aminotransferase; $A S T$, aspartate aminotransferase.

TABLE E4. Average cardiac dimensions and mechanics from echocardiography (short axis plane - mid papillary muscle level)

\begin{tabular}{lccccccc}
\hline \multicolumn{1}{c}{ Group: } & $\begin{array}{c}\text { Diastolic total } \\
\text { area }\left(\mathbf{m}^{\mathbf{2}}\right)\end{array}$ & $\begin{array}{c}\text { Diastolic cavity } \\
\text { area }\left(\mathbf{m}^{\mathbf{2}}\right)\end{array}$ & $\begin{array}{c}\text { LV diastolic internal } \\
\text { diameter }(\mathbf{c m})\end{array}$ & $\begin{array}{c}\text { Systolic total } \\
\text { area }\left(\mathbf{m}^{\mathbf{2}}\right)\end{array}$ & $\begin{array}{c}\text { Systolic cavity } \\
\text { area }\left(\mathbf{m}^{\mathbf{2}}\right)\end{array}$ & $\begin{array}{c}\text { LV systolic internal } \\
\text { diameter }(\mathbf{c m})\end{array}$ & $\begin{array}{c}\text { Ejection } \\
\text { fraction }(\%)\end{array}$ \\
\hline Normal sheep & 24.7 & 11.9 & 3.2 & 19.8 & 5.4 & 2.2 & 65.0 \\
GPF sheep & 23.8 & 12.0 & 3.1 & 19.8 & 5.4 & 2.3 & 57.3 \\
\hline
\end{tabular}

$L V$, Left ventricular; GFP, green fluorescent protein. 